\title{
Effect of highly lipolyzed goat cheese on HL-60 human leukemia cells: Antiproliferative activity and induction of apoptotic DNA damage
}

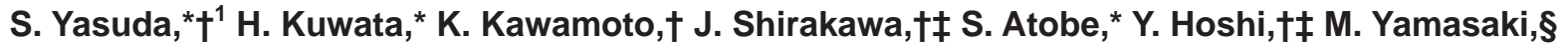 \\ K. Nishiyama,§ H. Tachibana,\# K. Yamada,\# H. Kobayashi, ${ }^{\star} \dagger$ and K. Igoshi† \\ *Department of Bioscience, School of Agriculture, \\ †Agricultural Sciences, Graduate School of Agriculture, and \\ fDepartment of Plant Science, School of Agriculture, Tokai University, Kawayo, Minamiaso, Aso, Kumamoto 869-1404 Japan \\ $\S$ Department of Biochemistry and Applied Biosciences, Faculty of Agriculture, University of Miyazaki, Miyazaki 889-2192 Japan \\ \#Division of Applied Biological Chemistry, Department of Bioscience and Biotechnology, Faculty of Agriculture, Kyushu University, \\ Fukuoka 812-8581 Japan
}

\section{ABSTRACT}

To establish cheese as a dairy product with health benefits, we embarked on examining the multifunctional role of cheeses, especially in the field of cancer prevention. The current study was designed to investigate whether different types of commercial goat cheeses may possess antiproliferative activity, using an HL-60 human promyelocytic leukemia cell line as a cancer cell model. Among 11 cheese extracts tested at $500 \mu \mathrm{g} / \mathrm{mL}$, 6 (Crottin de Chavignol, Pouligny Saint-Pierre, Chabichou du Poitou, Valencay, Kavli, and Sainte-Maure de Touraine) resulted in a significant decrease of cell viability, which is consistent with a decrease in viable cell number. Compared with the half-maximal inhibitory concentration $\left(\mathrm{IC}_{50}\right)$ value of individual cheeses in cellular proliferation assays, the Pouligny Saint-Pierre extract showed strong inhibition. Incubation of cells in the presence of Pouligny Saint-Pierre extract resulted in induction of cellular morphological changes and apoptotic DNA fragmentation as well as expression of the active form of caspase- 3 protein. Based on the quantification of the ratio of free fatty acids to triglycerides in different cheese samples, a significant correlation was detected between lipolytic ripeness and $\mathrm{IC}_{50}$ values for antiproliferative capacity tested in HL-60 cells. Collectively, these results support a potential role of highly lipolyzed goat cheeses in the prevention of leukemic cell proliferation.

Key words: cheese, antiproliferation, leukemia, lipolysis

Received January 6, 2011.

Accepted January 7, 2012.

${ }^{1}$ Corresponding author: shin.yasuda@agri.u-tokai.ac.jp

\section{INTRODUCTION}

Cheese is a well-known fermented food product that is widely produced throughout the world from the milk of cow, goat, or other ruminants. Because of the nutritional ingredients of fermented milk products (e.g., FFA, proteins, and peptides), numerous studies have been conducted to investigate the health benefits of consuming them (Woo et al., 1984; Collins et al., 2003; Meisel, 2004). During cheese ripening, bacterial lipolytic and proteolytic enzymes provide more bioactive compounds than are found in fresh cheese (Matar et al., 1996, 2003; Roy et al., 1999; Sousa et al., 2001; Collins et al., 2003; Inayat et al., 2003). Recent studies have demonstrated that certain compounds, especially peptides, found in fermented milk products may exhibit various physiological functions, such as cardiovascular protective effects in humans (Phelan and Kerins, 2011; Urista et al., 2011). A bovine casein-derived peptide generated during ripening of Edam cheese has been found to demonstrate inhibition activity in the intestinal absorption of $\beta$-LG (Tanabe et al., 2003), whereas other casein-derived peptides generated in fermented milk products have been shown to serve as antioxidative (Kudoh et al., 2001) and antihypertensive (Yamamoto et al., 1999) agents. We previously demonstrated a significant correlation between antioxidative activity of various cow cheese extracts and their peptide contents (Igoshi et al., 2008). Free fatty acids liberated in cheeses are derived from lipolyzed short- and medium-chain fatty acids under the action of bacterial lipases and esterases during fermentation (Collins et al., 2003). It has been shown that FFA can be formed in goat cheeses during ripening (Attaie and Richter, 1996). In relation to bacterial lipolysis, FFA have been demonstrated to be one of the key groups of compounds in directly regulating apoptotic cell death as well as lipid-metabolism-mediating cell death in vitro (Kuhajda et al., 1994; Yu et al., 2008). Several 
studies have demonstrated the presence of relatively minor but physiologically highly active FFA, such as conjugated linoleic acid, branched-chain fatty acids, and short-chain fatty acids in goat cheeses (Alonso et al., 1999; Mir et al., 1999; Poveda and Cabezas, 2006; Hijova and Chmelarova, 2007), particularly with regard to their anticancer effects (Yamada et al., 1985; Chujo et al., 2003; Hijova and Chmelarova, 2007; Dailey et al., 2011). Studies have also implicated short-chain fatty acids generated from prebiotics in reducing the risk of developing gastrointestinal disorders, cardiovascular disease, cancer, and inflammation (Wong et al., 2006; Havenaar, 2011). Whether the active molecule(s) (e.g., possibly FFA or peptides) present in these cheeses exert a cancer-preventive effect is an interesting question for further investigation.

With regard to cancer prevention and treatment, a considerable number of studies have indicated that dairy and natural food products may possess anticancer activity (Ip et al., 2003; Kandaswami et al., 2005; Parodi, 2007). Enzymatically digested skim milk or fermented milk cultured with various lactic acid bacteria and yeast can exhibit differential suppressive activities on the cell growth of human leukemia cells (Ito et al., 1998; Roy et al., 1999). By serving as an apoptotic inducer on tumor development, compounds found in cow milk (e.g., lactoferrin and lactoferricin) can suppress the growth of cancer cells in vitro and in vivo (Roy et al., 2002; de Moreno de LeBlanc et al., 2005; Mader et al., 2005; Xu et al., 2010). In our recent report, highly ripened cow milk cheeses were capable of demonstrating antiproliferative activity and induction of apoptotic DNA damage on HL-60 cells (Yasuda et al., 2010). However, the functional role of goat milk cheeses remains to be entirely clarified. We were interested, therefore, in examining the differential antiproliferative effects of various commercial goat cheeses with different lipid contents on cancer cell growth in vitro.

In this study, we investigated the potential role of commercial goat cheese products on the cell growth and induction of DNA fragmentation in HL-60 human promyelocytic leukemia cells as a cancer model. The HL-60 cell line was chosen because of a valid and useful model for discovery of cancer chemopreventive or chemotherapeutic agents from natural products (Gorczyca et al., 1993; Suh et al., 1995; Roy et al., 1999, 2002; Kawaii and Lansky, 2004; Yu et al., 2008). A systematic investigation of the differential antiproliferative activities of the 11 commercial goat cheese samples was performed. Moreover, the evaluation of associations between the lipolytic ripeness of individual cheese and the antiproliferative capacity examined in HL-60 cells was carried out.

\section{MATERIALS AND METHODS}

\section{Materials}

Eleven commercial cheese products (Banon, Buchettes, Chabichou du Poitou, cheese spread from creamy ERU Chevre doux, Crottin de Chavignol, Kavli, Piramid Cendre, Pouligny Saint-Pierre, Sainte-Maure Soignon, Sainte-Maure de Touraine, and Valencay) imported from overseas were purchased from retail stores (Kumamoto, Japan) and stored at $-20^{\circ} \mathrm{C}$ until use. The HL-60 human promyelocytic leukemia cells (JCRB0085) were obtained from Japanese Collection of Research Bioresources (Tokyo, Japan). Cisplatin, RPMI-1640 medium, and anti- $\beta$-actin antibody were from Sigma Chemical Co. (St. Louis, MO). Fetal bovine serum was purchased from Biowest (Nuaille, France). Cell counting kit-8 containing 2-(2-methoxy-4-nitrophenyl)3-(4-nitrophenyl)-5-(2,4-disulfophenyl)-2H-tetrazolium monosodium salt (WST-8), 1-methoxy-5-methylphenazinium-methyl-sulfate, and Hoechst 33258 solution were products of Dojindo Labs (Kumamoto, Japan). Agarose S, gene ladder 100, loading buffer, NEFA-C test, triglycerides-E test, and phorbol 12-myristate 13-acetate (PMA) were from Wako Chemicals (Osaka, Japan). Sodium chloride, penicillin G, streptomycin sulfate, dimethyl sulfoxide (DMSO), proteinase $\mathrm{K}$, RNase, ethidium bromide, protease inhibitor cocktail, and BSA were products from Nacalai Tesque Inc. (Kyoto, Japan). Trypan blue solution $(0.4 \%)$ was purchased from Gibco-Invitrogen (Carlsbad, CA). Anti-cleaved caspase-3 and anti-rabbit-IgG horseradish peroxidase conjugate antibodies were from Cell Signaling (Danvers, MA). Can Get Signal immunoreaction enhancer solutions were purchased from Toyobo Life Science (Osaka, Japan) and PVDF Hybond-P membrane and ECL-plus Western blotting detection kit were from Amersham-Pharmacia Biotech (Buckinghamshire, UK) and GE Healthcare Bio-Sciences (Piscataway, NJ), respectively. All other chemicals were of the highest grade commercially available.

\section{Preparation of Cheese Extracts}

Methanol, in combination with chloroform, has been used in the extraction of hydrophobic peptides and lipids (Schul et al., 1998; McSweeney and Fox, 1999). Several studies have used methanol extraction in the detection of bioactive chemicals such as amines and antibiotics from cheeses and other foods (Walters, 1984; AOAC, 1995; Clark et al., 2005; Custodio et al., 2007). In this study, the cheese extract was prepared from individual samples by a previously reported methanol 
extraction method (Yasuda et al., 2010). Briefly, dried cheese samples were first prepared from approximately $3 \mathrm{~g}$ (fresh weight) of manufactured cheeses by lyophilization and crushed. Thereafter, $0.75 \mathrm{~g}$ of dried cheese samples was mixed with $5 \mathrm{~mL}$ of methanol at room temperature $\left(\sim 20^{\circ} \mathrm{C}\right)$. The cheese suspension thus obtained was homogenized 3 times for $30 \mathrm{~s}$ each using a homogenizer (UltraTurrax TP18/10S4 type, Yamato Scientific Co., Ltd., Tokyo, Japan). After centrifugation at $600 \times g$ for 20 min at room temperature, the precipitates were homogenized using $5 \mathrm{~mL}$ of methanol. One milliliter of the combined supernatant was collected and allowed to dry using a centrifugal evaporator (CVE-2000, EYELA, Tokyo Rikakikai Co. Ltd., Tokyo, Japan) at room temperature $\left(\sim 20^{\circ} \mathrm{C}\right)$. Subsequently, the resulting cheese extracts were redissolved in DMSO as stock solutions for the cell proliferation assay.

\section{Measurement of FFA and Triglycerides}

The amounts of FFA and triglycerides (TG) in individual cheese extracts were determined by enzymatic methods using the commercially available NEFA-C and TG-E test kits, respectively. According to manufacturer's instructions, FFA (equal to NEFA; $\mu \mathrm{Eq} / \mathrm{mg}$ of extract) and TG contents $(\mu \mathrm{g} / \mathrm{mg}$ of extract), respectively, were photometrically analyzed at 600 and 550 nm using an SH-1000Lab Grating Microplate Reader (Corona Electric, Ibaragi, Japan). These test kits have been available for in vitro diagnostic use with biological specimens based on the biochemical approaches. Lipolytic ripeness (FFA:TG ratio, $\mu \mathrm{Eq} / \mu \mathrm{g}$ ) of individual cheese samples was calculated based on the ratio of FFA content against TG content in cheese extracts as determined above.

\section{Trypan Blue Dye Exclusion Assay for Viability of HL-60 Cells}

The HL-60 human promyelocytic leukemia cells were routinely maintained under a $5 \% \mathrm{CO}_{2}$ atmosphere at $37^{\circ} \mathrm{C}$ in RPMI-1640 medium supplemented with $5 \%$ fetal bovine serum, $100 \mathrm{U} / \mathrm{mL}$ penicillin $\mathrm{G}$, and $100 \mu \mathrm{g} /$ $\mathrm{mL}$ streptomycin sulfate. For the cell viability assay, HL-60 cells were seeded in individual wells of a 96well culture plate at a density of $5 \times 10^{4}$ cells $/ 100 \mu \mathrm{L}$ per well in the same medium. Therein, $1 \mu \mathrm{L}$ of cheese extract, reconstituted in DMSO, was added to each well. Upon a 24 -h incubation, $10 \mu \mathrm{L}$ of cell suspension was mixed with the same amount of $0.4 \%$ trypan blue solution. After a 3-min incubation at room temperature $\left(\sim 20^{\circ} \mathrm{C}\right)$, the cells were mounted on a Burker-Turk-type hemocytometer and counted as trypan blue-penetrated (dead) cells or nonpenetrated (viable) cells using an inverted microscope.

\section{Proliferation Assay of HL-60 Cells}

For the cell proliferation assay, HL-60 cells were seeded in individual wells of a 96-well culture plate at a density of $5 \times 10^{4}$ cells $/ 100 \mu \mathrm{L}$ per well in the presence of varying concentrations of cheese samples. A cell counting kit was used to measure the activities of dehydrogenase enzyme(s) in viable cells according to the manufacturer's instructions. After incubation for $24 \mathrm{~h}, 10 \mu \mathrm{L}$ of $5 \mathrm{~m} M$ WST-8 solution containing 0.2 $\mathrm{m} M$ 1-methoxy-5-methylphenazinium-methyl-sulfate and $150 \mathrm{mM} \mathrm{NaCl}$ was added to each well, followed by another $3 \mathrm{~h}$ of incubation. The reduction of WST8 was determined colorimetrically at $450 \mathrm{~nm}$ using a microplate reader.

\section{Evaluation of Nuclear Morphological Changes in HL-60 Cells}

Apoptotic cell death was semiquantitatively evaluated by fluorescence microscopy after staining with Hoechst 33258 as described previously (Yasuda et al., 2010). Cells grown in a 30-mm tissue culture dish (density of $1 \times 10^{6}$ cells $/ \mathrm{mL}$ ) were incubated with $2 \mathrm{~mL}$ of culture medium in the presence of Pouligny Saint-Pierre cheese extract ranging from 50 to $250 \mu \mathrm{g} / \mathrm{mL}$. After 0,6 , or 12 $\mathrm{h}$ of incubation, the cells were collected in a microtube, fixed with PBS containing 1\% glutaraldehyde, and kept at room temperature overnight and thereafter at $4^{\circ} \mathrm{C}$ for $3 \mathrm{~d}$. The cells were washed with $1 \mathrm{~mL}$ of PBS and suspended in $50 \mu \mathrm{L}$ of PBS, and cells in $7.5-\mu \mathrm{L}$ aliquot of the suspension were stained with $1.5 \mu \mathrm{L}$ of $1 \mathrm{mM}$ Hoechst 33258 following observation of nuclear morphological changes using an Olympus BX51 fluorescent microscope at $200 \times$ magnification (Olympus Optical Co. Ltd., Tokyo, Japan). Digital photo data were taken using a Photometric Sensys camera were analyzed using Sensys MetaMorph software (Roper Scientific Inc., Tucson, AZ).

\section{Analysis of DNA Fragmentation in HL-60 Cells}

For visualization of DNA fragmentation, HL-60 cells grown in a 30-mm tissue culture dish (density at $5 \times$ $10^{5}$ cells per $2 \mathrm{~mL}$ ) were incubated in the presence of varying concentrations of cheese extract as described previously (Yasuda et al., 2010). After $6 \mathrm{~h}$ of incubation, the cells were collected after centrifugation at 400 $\times g$ for $5 \mathrm{~min}$ at room temperature $\left(\sim 20^{\circ} \mathrm{C}\right)$, washed twice with $1 \mathrm{~mL}$ of PBS, and lysed for $10 \mathrm{~min}$ on ice in $130 \mu \mathrm{L}$ of lysis buffer $(10 \mathrm{~m} M$ Tris- $\mathrm{HCl}$ buffer, $\mathrm{pH}$ 
7.4, $10 \mathrm{~m} M$ EDTA, and 0.5\% Triton X-100). After centrifugation at $20,000 \times g$ for $20 \mathrm{~min}$ at $4^{\circ} \mathrm{C}, 100 \mu \mathrm{L}$ of supernatant containing DNA was collected and treated with $400 \mu \mathrm{g} / \mathrm{mL}$ of RNase A for $1 \mathrm{~h}$ at $37^{\circ} \mathrm{C}$ and with $300 \mu \mathrm{g} / \mathrm{mL}$ of proteinase $\mathrm{K}$ for another $30 \mathrm{~min}$ at $50^{\circ} \mathrm{C}$. Thereafter, DNA was precipitated with an additional $120 \mu \mathrm{L}$ of isopropanol plus $20 \mu \mathrm{L}$ of $5 \mathrm{M} \mathrm{NaCl}$ overnight at $-20^{\circ} \mathrm{C}$. The DNA precipitates, dissolved in $12 \mu \mathrm{L}$ of Tris-EDTA buffer containing $10 \mathrm{~m} M$ Tris- $\mathrm{HCl}, \mathrm{pH}$ 7.4, and $1 \mathrm{~m} M$ EDTA, were applied onto a $2 \%$ agarose gel, electrophoretically separated using iMyRunNC (Cosmo Bio Co. Ltd., Tokyo, Japan), and visualized by ethidium bromide staining.

\section{Western Blot Analysis of Cleaved Caspase-3 and $\beta$-Actin in HL-60 Cells}

For the detection of cleaved caspase- 3 and $\beta$-actin proteins, HL-60 cells grown in a $30-\mathrm{mm}$ tissue culture dish (density of $1 \times 10^{6}$ cells $/ \mathrm{mL}$ ) with $2 \mathrm{~mL}$ of culture medium were incubated in the presence of varying concentrations of cheese extract. After $12 \mathrm{~h}$ of incubation, the cells were washed with $1 \mathrm{~mL}$ of PBS, and lysed with $200 \mu \mathrm{L}$ of RIPA buffer (50 mM Tris-HCl buffer, pH 7.5, $150 \mathrm{mM} \mathrm{NaCl}, 1 \%$ Triton X-100, and $1 \%$ sodium cholate) containing $1 \%$ protease inhibitor cocktail. The crude cell lysates were centrifuged at $1,500 \times g$ for $10 \mathrm{~min}$ at $4^{\circ} \mathrm{C}$ to remove cell debris. The supernatants collected were used for Western blot analysis. Protein determination was based on the method of Bradford with BSA as the standard (Bradford, 1976). To measure cleaved caspase- 3 and $\beta$-actin protein expression in the cells, aliquots $(5 \mu \mathrm{g})$ of the cell lysates were subjected to $10 \%$ SDS-PAGE at $0.04 \mathrm{~A}$ for $1 \mathrm{~h}$ and subsequently electrotransferred onto a PVDF Hybond-P membrane at 100 $\mathrm{V}$ for $45 \mathrm{~min}$ as described previously (Yamasaki et al., 2010). For the detection of cleaved caspase-3 protein, the ECL-plus Western blotting detection kit was used according to the manufacturer's instructions. Briefly, after blocking in 5\% nonfat milk in Tris-buffered saline containing $0.1 \%$ Tween-20 (T-TBS), the membrane was incubated with primary antibody against cleaved caspase- 3 at a 1:2,000 dilution in Can Get Signal immunoreaction enhancer solutions 1 and 2 for overnight at $4^{\circ} \mathrm{C}$. In the case of $\beta$-actin, the membrane was incubated with primary antibody against $\beta$-actin at 1:5,000 for 1 $\mathrm{h}$ at room temperature. Subsequently, the membrane was washed with T-TBS and incubated with secondary antibody conjugated with HRP at 1:2,000 dilution in Can Get Signal solutions for $1 \mathrm{~h}$ at room temperature. After washings with T-TBS, protein bands of cleaved caspase- 3 and $\beta$-actin was visualized on a luminescent image analyzer (LAS-1000, Fujifilm, Tokyo, Japan) using an ECL-plus system.

\section{Miscellaneous Methods}

Differentiated HL-60 cells were obtained as mentioned previously (Das et al., 2000; Oda et al., 2007). Briefly, HL-60 cells seeded in individual wells of 96-well plate at a density of $1 \times 10^{5}$ cells $/ 100 \mu \mathrm{L}$ per well were preincubated in the presence of $20 \mathrm{n} M$ PMA for $48 \mathrm{~h}$. Adherent cells were used for experiments as differentiated HL-60 cells. Mouse splenocytes were prepared as described previously (Kimoto et al., 2004). Briefly, the spleen was excised from an adult female mouse (32-wkold Sea:ddy strain, Kyudo Inc., Kumamoto, Japan) sedated under diethyl ether anesthesia. Splenocytes, isolated using erythrocyte lysis buffer (containing 0.15 $M \mathrm{NH}_{4} \mathrm{Cl}, 10 \mathrm{mM} \mathrm{KHCO}_{3}$, and $0.1 \mathrm{~m} M$ EDTA), were inoculated at a density of $5 \times 10^{5}$ cells $/ 100 \mu \mathrm{L}$ per well in RPMI-1640 medium containing fetal bovine serum. All animal experiments were performed in accordance with the guidelines of the Committee on Ethical Animal Care and Use of Tokai University.

\section{Statistical Analysis}

The values are expressed as means \pm standard deviation derived from 3 or 4 parallel experiments from individual cheese extracts. Data were analyzed using a statistical add-on software program (Statcel, OMS Co., Saitama, Japan) for Excel 2004 (Microsoft Corp., Redmond, WA). Statistical differences between control and test sample-treated cells were considered significant at $P<0.05, P<0.01$, or $P<0.001$ using Student's $t$-test. Evaluation of the associations between lipid parameters (FFA and TG contents, and lipolytic ripeness defined as FFA:TG ratio, $\mu \mathrm{Eq} / \mu \mathrm{g}$ ) and growth inhibition index [half-maximal inhibitory concentration $\left(\mathbf{I C}_{50}\right)$ value, $\mu \mathrm{g} / \mathrm{mL}]$ was carried out using the Spearman rank correlation test; $P<0.05$ was considered statistically significant.

\section{RESULTS AND DISCUSSION}

The objective of the current study was to investigate the antiproliferative effects of commercial goat cheese products and the potential role the products have in induction of DNA damage in HL-60 human leukemia cells as a cancer model. In our previous report, highly ripened cow milk cheeses were capable of demonstrating antiproliferative activity and induction of apoptotic DNA damage on HL-60 cells (Yasuda et al., 2010). Several reports have demonstrated that bacterial lipolytic and proteolytic enzymes increased the levels of bioactive compounds during milk fermentation (Matar et al., 1996, 2003; Roy et al., 1999; Sousa et al., 2001; Collins et al., 2003; Inayat et al., 2003). However, the 
functional role of goat milk cheeses remains to be clarified. We therefore were interested in examining the differential antiproliferative effects of various commercial goat cheeses with different lipid contents on cancer cell growth in vitro.

\section{Preparation and Lipid Analyses of Goat Cheeses}

We first prepared methanol extracts prepared from 11 commercial goat cheeses, and investigated the lipid contents in these cheese extracts. As shown in Table 1, lyophilization of 3-g samples of crushed fresh cheeses yielded dried weights in the range of 1.24 to $1.78 \mathrm{~g}$. Yield of methanol extraction from $1 \mathrm{~g}$ of dried cheese resulted in 0.166 to $0.478 \mathrm{~g}$ of dry matter. To characterize these cheeses by lipid content, levels of FFA and TG were analyzed using commercially available colorimetric kits. For FFA and TG, contents of 0.0700 to $13.7 \mu \mathrm{Eq} / \mathrm{mg}$ of extract and 7.00 to $31.7 \mu \mathrm{g} / \mathrm{mg}$ of extract, respectively, were obtained. The FFA liberated in cheeses result from lipolysis of short- and mediumchain fatty acids by bacterial lipases and esterases during fermentation (Collins et al., 2003). It is important to note that FFA can be formed in goat cheeses during ripening (Attaie and Richter, 1996). Because TG is the major constituent of milk lipid (more than 90\%), the data showing relatively higher FFA content but lower TG content in goat cheeses in this study may result from their lipolytic ripeness.

\section{Cytotoxic Activity of Commercial Goat Cheeses in HL-60 Cells}

In this study, we investigated the cytotoxic effects of methanol extracts prepared from 11 commercial cheeses using HL-60 human promyelocytic leukemia cells. The
HL-60 cell line was chosen because it is a valid and useful model for discovery of cancer chemopreventive or chemotherapeutic agents from natural products (Gorczyca et al., 1993; Suh et al., 1995; Roy et al., 1999, 2002; Kawaii and Lansky, 2004; Yu et al., 2008). Cell viability was obtained based on the number of viable cells (no penetration of trypan blue) and dead cells (penetrated with trypan blue) counted microscopically. As shown in Figure 1A, the viable cell count revealed that 5 cheese extracts (Piramid Cendre, Buchettes, Banon, cheese spread, and Sainte-Maure Soignon) tested at 200 and $500 \mu \mathrm{g} / \mathrm{mL}$ exhibited a slight but not significant decrease in HL-60 cells, whereas 1 cheese extract (Kavli) at $500 \mu \mathrm{g} / \mathrm{mL}$ showed a strong but not significant decrease. The other 5 cheese extracts (Sainte-Maure de Touraine, Valencay, Chabichou du Poitou, Pouligny Saint-Pierre, and Crottin de Chavignol) displayed a significant decrease in viable cell number at $500 \mu \mathrm{g} / \mathrm{mL}$ $(P<0.001)$. In Figure 1B, the data calculated from the rate of viable cells in total cells revealed a significant decrease of cell viability when cells were incubated in the presence of most of these cheese samples at $500 \mu \mathrm{g} /$ $\mathrm{mL}(P<0.001)$. Of these, Pouligny Saint-Pierre and Crottin de Chavignol demonstrated a lower viable cell number $\left(<15 \times 10^{4}\right.$ cells $\left./ \mathrm{mL}\right)$ and lower cell viability $(<25 \%)$, indicating a strong cytotoxic effect. As shown in Figure 2, HL-60 cells were cultured in the presence of varying concentrations of the 6 cheese extracts (Crottin de Chavignol, Pouligny Saint-Pierre, Chabichou du Poitou, Valencay, Kavli, and Sainte-Maure de Touraine) to measure the intensity of antiproliferative capacity of these cheeses based on the WST-8 cell proliferation assay system. Crottin de Chavignol, Pouligny Saint-Pierre, and Chabichou du Poitou showed concentration-dependent growth inhibition, with $\mathrm{IC}_{50}$ values of 310,164 , and $630 \mu \mathrm{g} / \mathrm{mL}$, respectively (Figure $2 \mathrm{~A}$ ).

Table 1. List of 11 commercial goat cheeses tested and lipid contents in individual cheese extracts ${ }^{1,2}$

\begin{tabular}{lcccc}
\hline Goat cheese & $\begin{array}{c}\mathrm{DW} \\
(\mathrm{g} / 3 \mathrm{~g} \text { of } \mathrm{FW})\end{array}$ & $\begin{array}{c}\text { Yield of extracts } \\
(\mathrm{g} / \mathrm{g} \text { of DW) }\end{array}$ & $\begin{array}{c}\mathrm{FFA} \\
(\mu \mathrm{Eq} / \mathrm{mg} \\
\text { of extract) }\end{array}$ & $\begin{array}{c}\mathrm{TG} \\
(\mu \mathrm{g} / \mathrm{mg} \\
\text { of extract) }\end{array}$ \\
\hline Banon & 1.45 & 0.256 & 2.37 & 9.67 \\
Buchettes & 1.78 & 0.166 & 2.37 & 8.00 \\
Chabichou du Poitou & 1.73 & 0.219 & 5.44 & 9.67 \\
Cheese spread & 1.29 & 0.191 & 0.63 & 10.3 \\
Crottin de Chavignol & 1.62 & 0.346 & 4.21 & 7.00 \\
Kavli & 1.75 & 0.338 & 6.97 & 31.7 \\
Piramid Cendre & 1.24 & 0.196 & 0.07 & 2.67 \\
Pouligny Saint-Pierre & 1.44 & 0.478 & 5.80 & 7.00 \\
Sainte-Maure Soignon & 1.53 & 0.250 & 5.75 & 7.33 \\
Sainte-Maure de Touraine & 1.63 & 0.347 & 9.07 & 19.0 \\
Valencay & 1.63 & 0.292 & 13.7 & 12.0 \\
\hline
\end{tabular}

${ }^{1} \mathrm{DW}=$ dry weight after lyophilization, $\mathrm{FW}=$ fresh weight; $\mathrm{TG}=$ triglycerides.

${ }^{2}$ Amounts of FFA and TG in cheese extracts were determined with some dilutions in the measurable range (FFA: $0.0500-2.00 \mu \mathrm{Eq} / \mathrm{mg}$ of cheese extract, TG: $0.720-100 \mu \mathrm{g} / \mathrm{mg}$ of cheese extract). 
Valencay, Kavli, and Sainte-Maure de Touraine showed $\mathrm{IC}_{50}$ values of 222,323 , and $801 \mu \mathrm{g} / \mathrm{mL}$, respectively (Figure 2B). A parallel experiment demonstrated 3.40 $\mu \mathrm{g} / \mathrm{mL}$ as the $\mathrm{IC}_{50}$ value in the presence of cisplatin (Figure 2C), an apoptosis-inducing agent (Gorczyca et al., 1993). In our previous report, blue cow cheese ripened for 1, 2, or 3 mo (compared with no ripening) was capable of causing strong suppression of cell growth and induction of apoptotic DNA damage (Yasuda et al., 2010). It is therefore conceivable that the suppressive effect of these individual cheeses may vary with their length of ripening. In another experimental setting, dose-dependent antiproliferation was observed in 3 other cheeses (Sainte-Maure Soignon, Banon, and Buchettes) with $\mathrm{IC}_{50}$ values ranging from 300 to 1,500 $\mu \mathrm{g} / \mathrm{mL}$ (305, 658, and $1,433 \mu \mathrm{g} / \mathrm{mL}$, respectively), whereas no strong growth inhibition was found in 2 other cheeses (cheese spread and Piramid Cendre; data not shown).

To confirm the concentration-dependent cytotoxic effect of Pouligny Saint-Pierre cheese extract in HL-60 cells, cell viability was microscopically investigated using the trypan blue dye exclusion assay. Pouligny SaintPierre cheese was chosen because it had the lowest $\mathrm{IC}_{50}$ value (Figure 2A). As shown in Figure 3A, Pouligny Saint-Pierre showed a concentration-dependent decrease in viable cell number and cell viability after a 24-h incubation. A parallel experiment confirmed that cisplatin also demonstrated a concentration-dependent decrease of viable cell number and viability in this assay (Figure 3B). Based on the counted viable cell number, the calculated $\mathrm{IC}_{50}$ values of Pouligny Saint-Pierre and cisplatin were 215 and $1.29 \mu \mathrm{g} / \mathrm{mL}$, respectively. Compared with the $\mathrm{IC}_{50}$ values obtained in Figure 2, these results differ because of the different methods used: the trypan blue dye exclusion assay is based on permeability of the cellular membrane, whereas the WST-8 proliferation assay is based on the intracellular enzymatic activity. However, it is important to note that the $\mathrm{IC}_{50}$ values demonstrated herein are similar (Figure 2). As shown in Figure 3C, phase-contrast microphotographs displayed obvious morphological changes in the HL-60 cells treated with Pouligny Saint-Pierre. To clarify the extent to which cells undergo apoptotic nuclear damage, morphological changes characteristic of apoptosis (e.g., chromatin condensation, blebbing, and fragmentation) were observed and semiquantitatively scored (Figure 4). The ratios of apoptotic cells (the nuclei with arrowheads in Figure 4, inset b) after 6 $\mathrm{h}$ of incubation in the presence of Pouligny Saint-Pierre cheese at 200 and $250 \mu \mathrm{g} / \mathrm{mL}$, respectively, were 13 and $14 \%$, both of which were significantly higher than that of control. After $12 \mathrm{~h}$ of incubation, a concentrationdependent increase in apoptotic cells was demonstrated to a maximum of $19 \%$ at $250 \mu \mathrm{g} / \mathrm{mL}$. The induction of apoptotic DNA fragmentation was subsequently analyzed. As visualized in Figure 4, inset c, we observed a dose-dependent increase in fragmented DNA when cells were incubated for $6 \mathrm{~h}$ in the presence of varying concentrations of Pouligny Saint-Pierre ranging from 50 to $250 \mu \mathrm{g} / \mathrm{mL}$. It is important to note that apoptotic cell death is also characterized by an acceleration of cleavage and activation of specific proteins such as caspase-3 (Liu et al., 1997). To gain insight into the involvement of a caspase-3-dependent apoptotic pathway in HL-60 cells, we examined whether Pouligny SaintPierre cheese could induce protein expression of cleaved caspase- 3 as an activated form. As shown in Figure 5, we observed a dose-dependent increase of the cleaved caspase-3 protein when cells were incubated for $12 \mathrm{~h}$ in the presence of Pouligny Saint-Pierre at concentrations ranging from 50 to $300 \mu \mathrm{g} / \mathrm{mL}$. In contrast to the increase of the expression of cleaved caspase- $3, \beta$-actin, a housekeeping protein, was steadily expressed throughout the experiment. However, we should emphasize that the distinct antiproliferative activity of the goat cheese extract needs to be quantitatively evaluated using a variety of apoptotic as well as necrotic indices (e.g., flow cytometric analyses staining with fluorescein isothiocyanate-conjugated annexin $\mathrm{V}$ and propidium iodide; terminal deoxynucleotidyl transferase-mediated dUTP nick-end labeling).

We subsequently investigated whether the antiproliferative effect of goat cheese found was specific not to normal cells but to cancer cells. As shown in Table 2 , the cytotoxic effect of Pouligny Saint-Pierre cheese extract was examined using differentiated HL-60 cells preincubated in the presence of PMA and primary mouse splenocytes. Because cancer cells are usually less differentiated than normal cells, cancer cells that underwent differentiation might be used as a model closer to normal cells (Das et al., 2000; Oda et al., 2007). The cytotoxic effect evaluated in differentiated HL-60 cells was much lower than that in undifferentiated HL-60 cells at concentrations of Pouligny Saint-Pierre ranging from 100 to $1,000 \mu \mathrm{g} / \mathrm{mL}$, whereas the cheese extract showed no drastic decrease in cell number in mouse splenocytes. However, a lesser extent of nonspecific cytotoxicity was observed at high concentrations of Pouligny Saint-Pierre cheese under this experimental setting. Although the results are controversial, an epidemiological study has demonstrated that a high consumption of fermented dairy products, such as yogurt and cheese, is statistically associated with a lower risk of colorectal cancer (Kampman et al., 2000) but not significantly associated with risk of lymphoma (Rohrmann et al., 2011). Whether the consumption of fermented goat milk cheeses is a risk preventive fac- 
A)

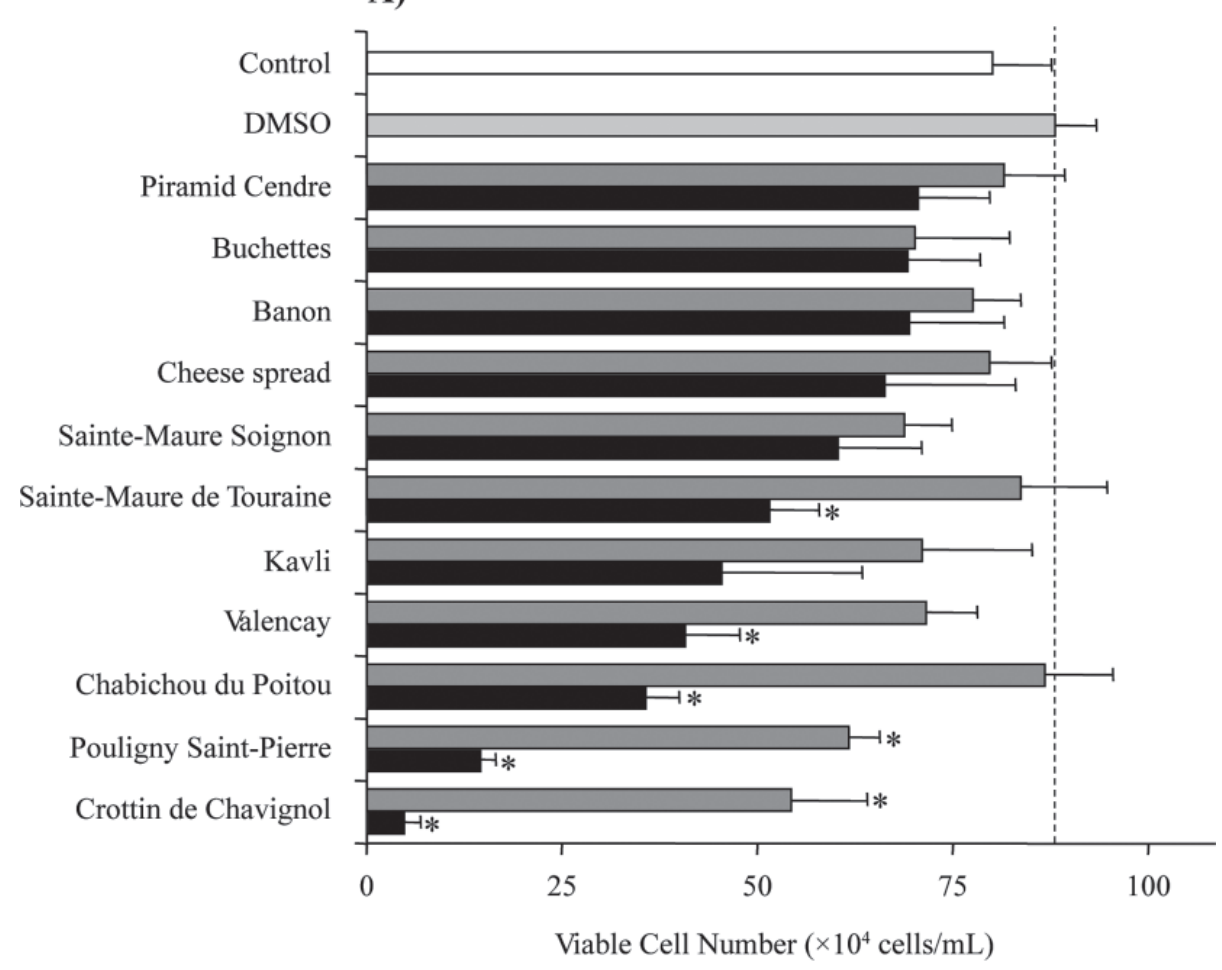

B)

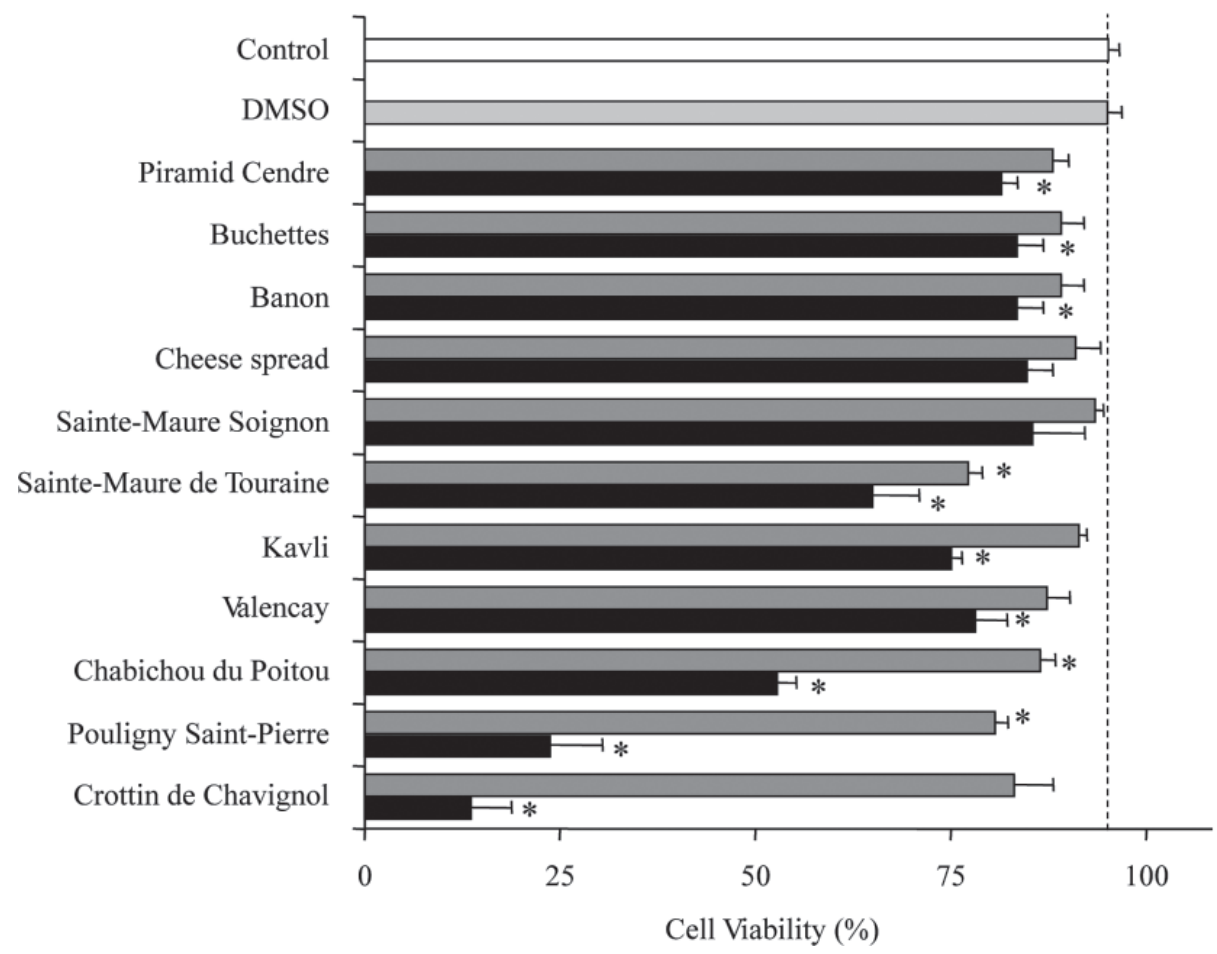

Figure 1. Effects of 11 different commercial goat cheeses on the viable cell number and cell viability in the HL-60 human promyelocytic leukemia cells. Cells seeded at $5 \times 10^{5}$ cells $/ \mathrm{mL}$ were incubated for $24 \mathrm{~h}$ in a 96 -well microplate in the presence of 11 commercial goat cheese extracts at $200 \mu \mathrm{g} / \mathrm{mL}$ (dark gray column) or $500 \mu \mathrm{g} / \mathrm{mL}$ concentration (black column). Control indicates cells treated with no samples; DMSO indicates cells treated with $1 \%$ dimethyl sulfoxide as a vehicle. Viable cell number (A) and cell viability (B) were calculated based on the cell number counted by using the trypan blue dye exclusion assay. Data shown represent mean \pm SD derived from 4 determinations of individual samples. *Statistical difference compared with the DMSO-treated cells in viable cell number or cell viability $(P<0.001)$. 

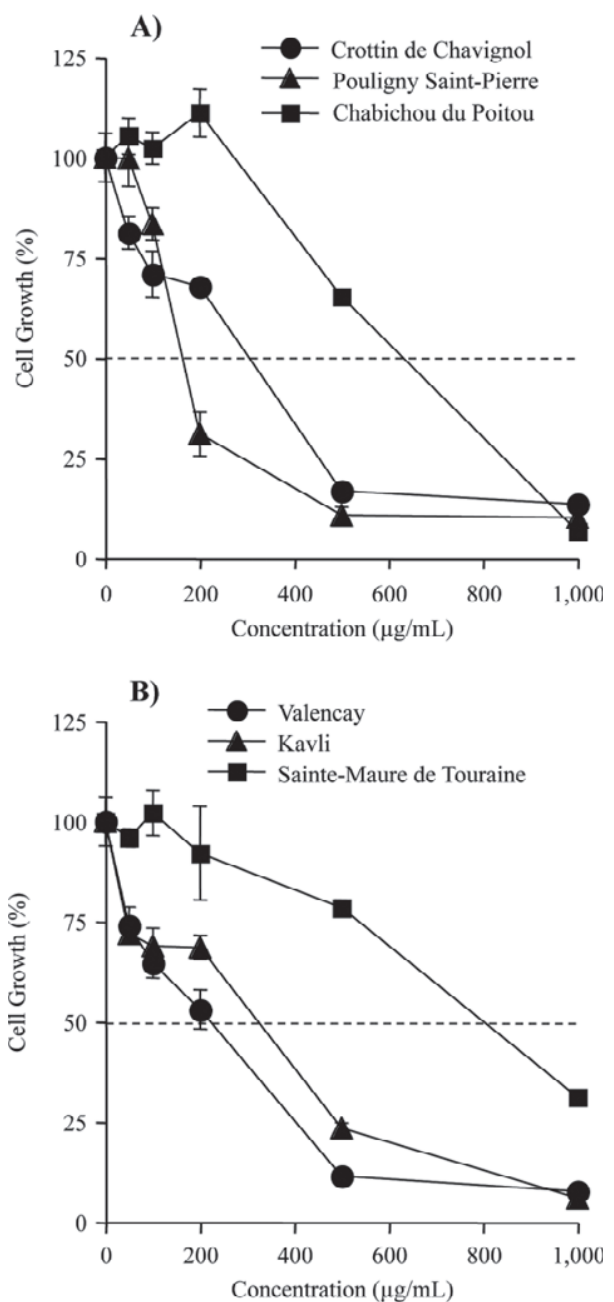

C)

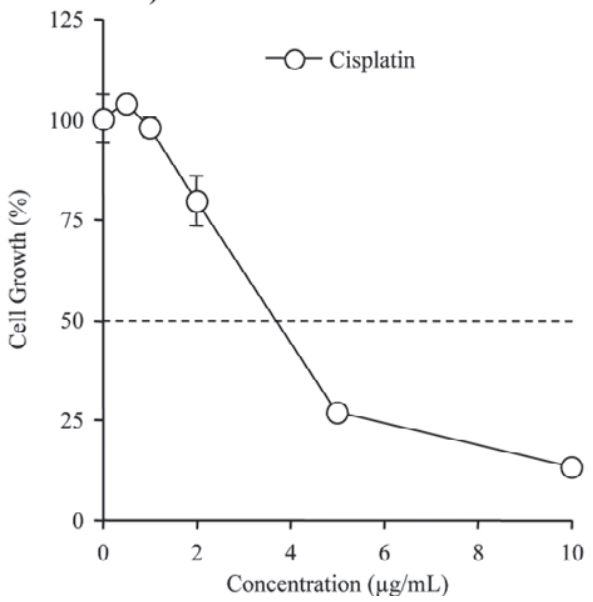

Figure 2. Effect of concentration on the antiproliferative activities of 6 commercial goat cheeses and cisplatin in HL-60 cells. Cells seeded at $5 \times 10^{5}$ cells $/ \mathrm{mL}$ were incubated in a 96-well microplate in the presence of varying concentrations of Crottin de Chavignol, Pouligny Saint-Pierre, or Chabichou du Poitou (A), Valencay, Kavli, Sainte Maure de Touraine (B), or cisplatin for $24 \mathrm{~h}$ (C). Cell growth rate was calculated based on the cell number measured by WST- 8 assay. Data shown represent mean \pm SD derived from 4 determinations of individual cheese samples or cisplatin (positive control).

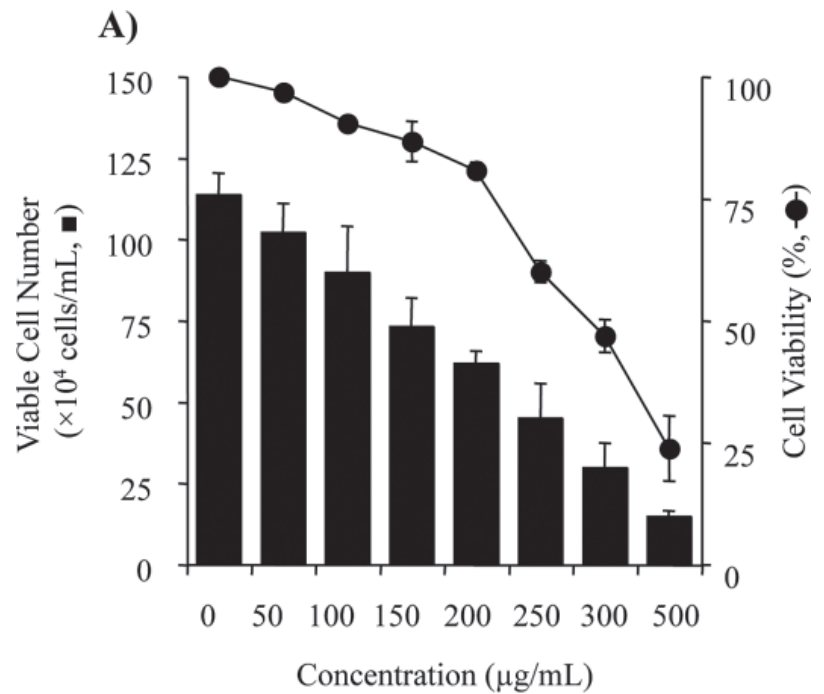

B)

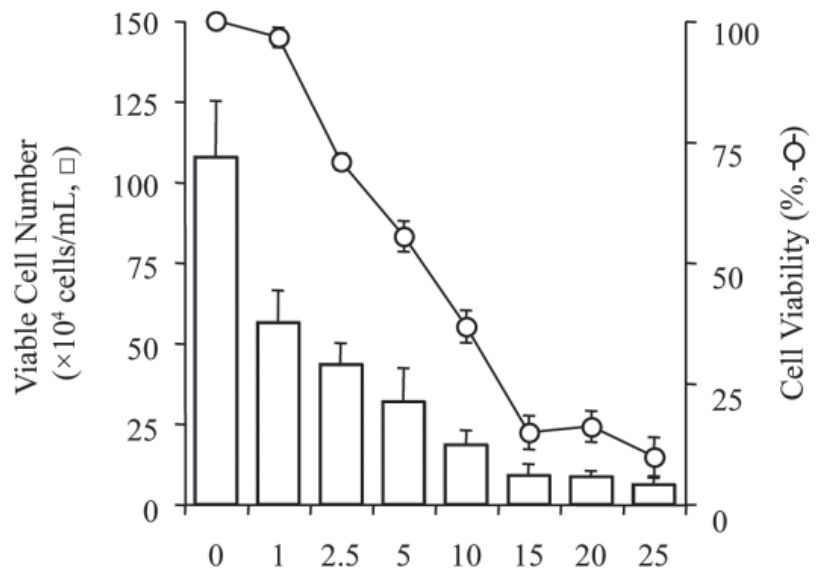

Concentration $(\mu \mathrm{g} / \mathrm{mL})$

C)

$$
\text { DMSO Pouligny }
$$

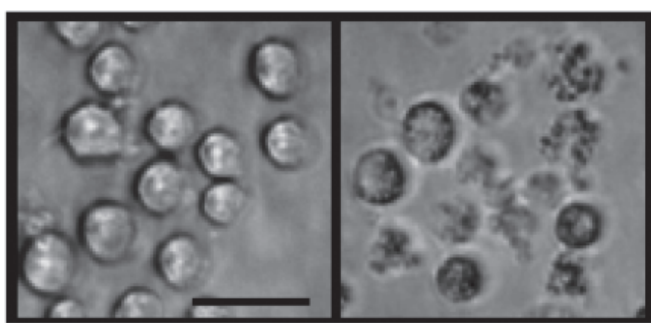

Figure 3. Effects of concentration of Pouligny Saint-Pierre and cisplatin on the viable cell number and cell viability in HL-60 cells. Cells seeded at $5 \times 10^{5}$ cells $/ \mathrm{mL}$ were incubated in a 96-well microplate in the presence of varying concentrations of Pouligny Saint-Pierre (A) or cisplatin for $24 \mathrm{~h}(\mathrm{~B})$. Viable cell number and cell viability were calculated based on the cell number counted by using the trypan blue dye exclusion assay. Data shown represent mean \pm SD derived from 4 determinations of individual samples or cisplatin (positive control). In (C), phase-contrast microphotographs of HL-60 cells were taken after 24 - $\mathrm{h}$ incubation in the presence or absence of $300 \mu \mathrm{g} / \mathrm{mL}$ Pouligny Saint-Pierre; dimethyl sulfoxide (DMSO) was added as a vehicle. The black scale bar indicates $100 \mu \mathrm{m}$. 


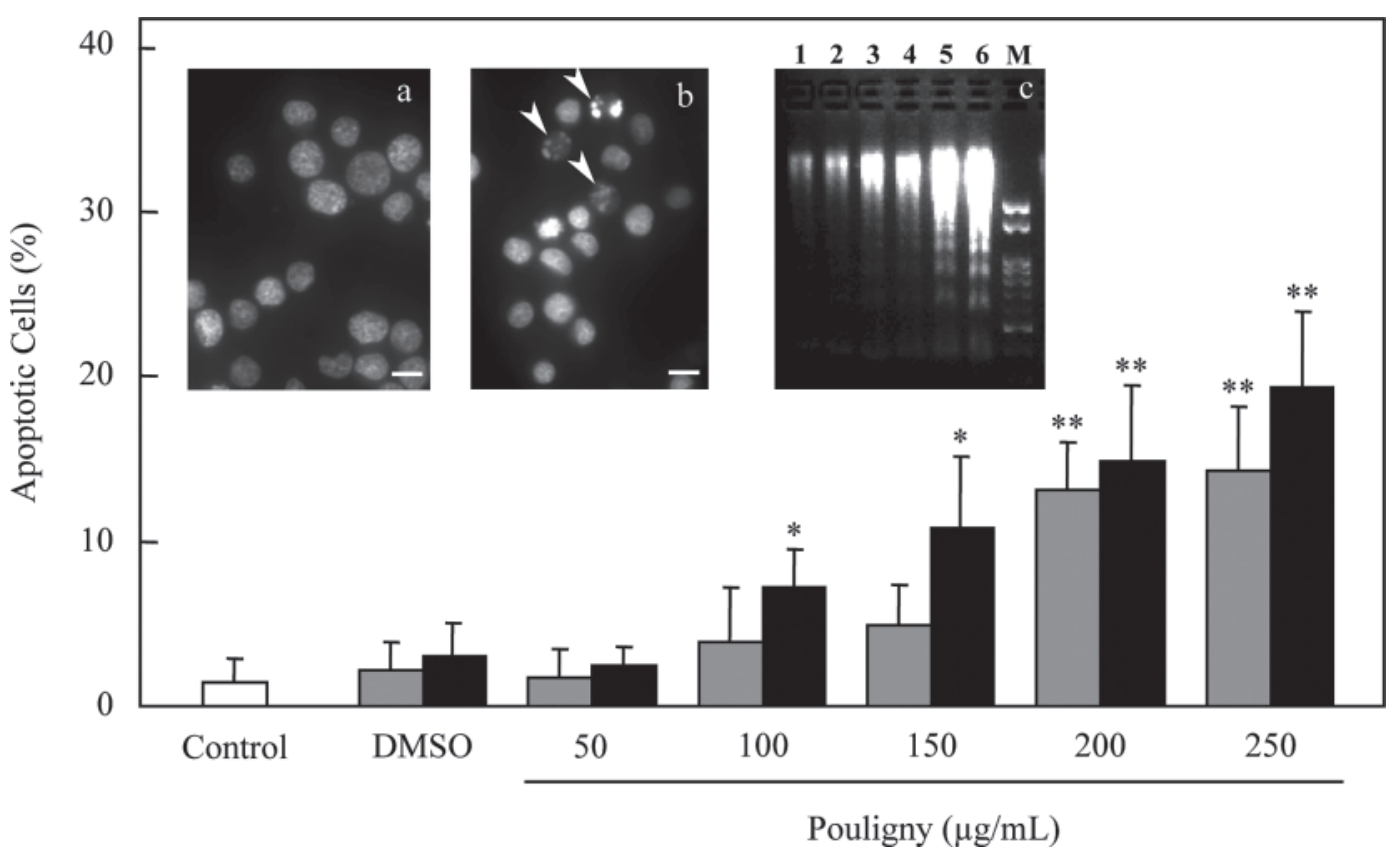

Figure 4. Evaluation of nuclear morphological changes and induction of DNA fragmentation in HL-60 cells after incubation in the presence of Pouligny Saint-Pierre cheese extract. Cells were incubated in the presence of the cheese at concentrations of 0 (dimethyl sulfoxide, DMSO), $50,100,150,200$, or $250 \mu \mathrm{g} / \mathrm{mL}$ for $6 \mathrm{~h}$ (gray column) or $12 \mathrm{~h}$ (black column). Control indicates the cells before test sample treatment (white column). Fluorescent nuclei were screened for normal or apoptotic nuclei (fragmented and condensed nuclei) as marked by arrowheads. The insets $\mathrm{a}$ and $\mathrm{b}$ show parts of representative fluorescence photomicrographs (observed area: $455 \times 365 \mu$ m; magnification: $200 \times$ ) taken for the nuclei of cells stained with Hoechst 33258 (a) before or (b) after $12 \mathrm{~h}$ of incubation with $250 \mu \mathrm{g} / \mathrm{mL}$ cheese extract. The white scale bar indicates $10 \mu \mathrm{m}$. Data represent mean \pm SD derived from 3 independent determinations, each carried out in duplicate. Statistical significance versus the ratio of apoptotic cells in control is indicated by asterisks $(* P<0.05 ; * P<0.01)$. Panel c shows the DNA fragmentation pattern of HL-60 cells taken from the agarose gel electrophoresis used for the analysis. Cells were incubated in the presence of Pouligny Saint-Pierre cheese sample at concentrations of 0 (DMSO), 50,100,150,200, or $250 \mu \mathrm{g} / \mathrm{mL}$ for $6 \mathrm{~h}$. Cellular DNA in each sample extracted was subjected to $2 \%$ agarose gel electrophoresis. Lane $1=$ control (0 cheese extract); lanes 2 to $6=$ Pouligny at 50, 100, 150, 200, and $250 \mu \mathrm{g} / \mathrm{mL}$, respectively; lane M = DNA size markers co-electrophoresed during agarose gel electrophoresis. The figure represents data from 3 independent repetitions.

tor for several types of cancer, including leukemia, is unknown because of the difficulty in commercial standardization of goat milk ingredients and composition compared with that of cow milk. In addition, different cheeses may have different compositions of bioactive components. It has also been reported that cow milk and its fermented products have potential cytotoxic properties against different types of tumor cells in vitro and against murine breast cancer in vivo (Ito et al., 1998; de Moreno de LeBlanc et al., 2005; Mader et al., 2005; Xu et al., 2010). Currently, no reports exist on the antileukemogenic activity of any cheeses, but a Lactobacillus casei strain, commercially used for making fermented milk products, is available in a mouse lymphoma model (Watanabe, 1996). Moreover, skim milk digested with a proteolytic enzyme from yeast can strongly inhibit the proliferation of HL-60 cells and induce apoptotic cell death, including the formation of apoptotic bodies and DNA fragmentation (Roy et al., 1999). In view of the fact that bacterial lipolytic and proteolytic enzymes may provide more bioactive compounds during milk fermentation (Matar et al., 1996,
2003; Roy et al., 1999; Sousa et al., 2001; Collins et al., 2003; Inayat et al., 2003), it might be interesting to clarify whether a relationship exists between growth inhibition activity in cancer cells and the level of active compounds among various goat cheeses. In bacterial lipolysis, the FFA generated are one of the key groups of compounds in directly regulating apoptotic cell death as well as lipid-metabolism-mediating cell death in vitro (Kuhajda et al., 1994; Yu et al., 2008). Nevertheless, it is important to identify and measure the levels of target compound(s) present in these cheeses. Whether the active molecules, possibly FFA, present in these cheeses exert cancer-preventive action will be an interesting question for further investigation.

\section{Correlation of Cytotoxic Activity and Lipid Contents of Goat Cheeses}

To investigate further the mechanism of the antiproliferative activities of goat cheeses in HL-60 cells, the relationship between lipid parameters (FFA and TG contents, and lipolytic ripeness defined as FFA:TG ra- 
Pouligny $(\mu \mathrm{g} / \mathrm{mL})$

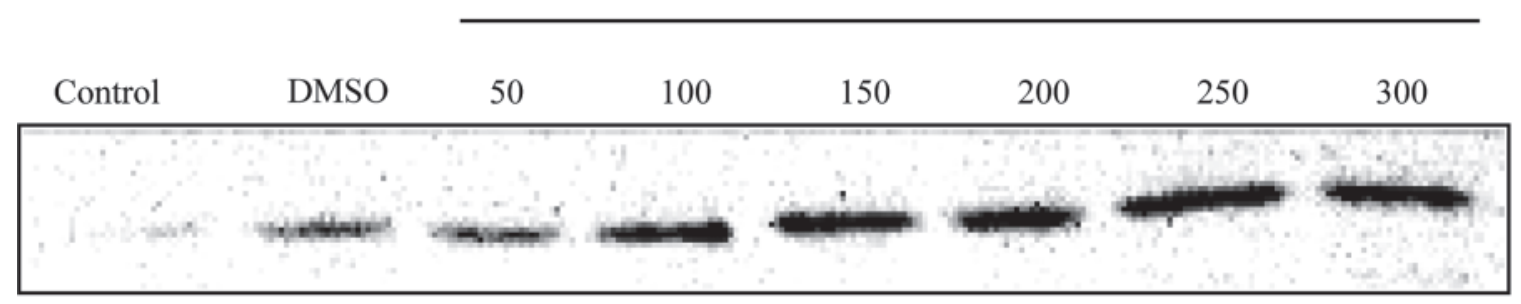

Cleaved Caspase-3

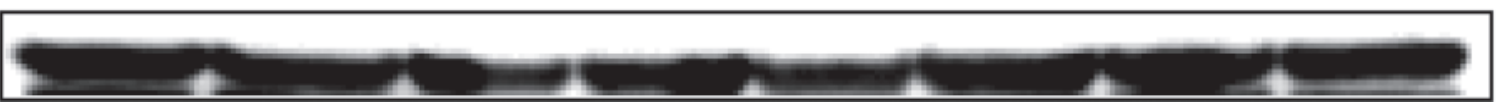

$\beta$-Actin

Figure 5. Detection of the active fragment of caspase-3 in HL-60 cells after incubation in the presence of Pouligny Saint-Pierre cheese extract. Cells were incubated in the presence of the cheese at concentrations of 0 (dimethyl sulfoxide, DMSO), 50, 100, 150, 200, 250, or 300 $\mu \mathrm{g} / \mathrm{mL}$. Control indicates the cells before test sample treatment. After a 12-h incubation, the expression of cleaved caspase-3 and $\beta$-actin proteins was individually analyzed using Western blotting technique. The figure represents data from 3 independent repetitions.

tio) in various goat cheeses and the growth inhibition capacity (defined as $\mathrm{IC}_{50}$ value) were analyzed. Figure $6 \mathrm{~A}$ shows that goat cheeses with a high FFA content seemingly exhibited strong growth inhibition (lower $\mathrm{IC}_{50}$ values), whereas 2 cheeses (cheese spread and Piramid Cendre) with a low FFA content demonstrated no apparent growth inhibition. However, FFA content in the other 9 cheeses were not significantly correlated with their $\mathrm{IC}_{50}$ values. Likewise, no significant correlation between $\mathrm{TG}$ content in cheeses and their $\mathrm{IC}_{50}$ values was observed (Figure 6B). Figure 6C shows the lipolytic ripeness exhibiting a significant correlation with the $\mathrm{IC}_{50}$ values in growth inhibition of various cheeses (Spearman rank correlation $=-0.767, P=0.030 ; \mathrm{n}$ $=9$ ), whereas 2 cheeses (cheese spread and Piramid Cendre) with low lipolytic ripeness demonstrated no apparent growth inhibition. This result implies that high-lipolyzed commercial goat cheeses may indeed possess antiproliferative activity against HL-60 cells rather than the low-lipolyzed cheeses in vitro. The question nevertheless remains as to the mechanism underlying the antiproliferative effects of high-lipolyzed cheeses on cancer cells. Several studies have demonstrated the presence of relatively minor but physiologically highly active FFA such as conjugated linoleic acid, branchedchain fatty acids, and short-chain fatty acids (e.g., butyric acid) in goat cheeses (Mir et al., 1999; Alonso et al., 1999; Poveda and Cabezas, 2006) with regard to their anticancer effects (Yamada et al., 1985; Chujo et al., 2003; Dailey et al., 2011). That the index of lipolysis correlates better than FFA content with $\mathrm{IC}_{50}$ values may be at least partially due to the effects of the characteristic FFA composition. In a previous report, we demonstrated a significant correlation between growth inhibition activity of 10 commercial cow milk cheeses and ripeness (defined as ratio of water-soluble nitrogen to total nitrogen content) in these cheeses (Yasuda et al., 2010). We were interested, therefore, in examining the relationship between the antiproliferative activity of goat cheeses and their lipolytic characteristics. We have also demonstrated a significant correlation between antioxidative activity of cow milk cheeses and peptide contents (Igoshi et al., 2008). Thus, highly lipolyzed goat cheese products indeed possess antiproliferative effect in the leukemia cell model, and lipolytic ripeness in cheeses can be considered as an important factor. In addition, cysteine-cysteine and $\gamma$-glutamylcyst(e) ine dipeptides originating from milk are thought to be

Table 2. Effect of Pouligny Saint-Pierre on cytotoxicity in the differentiated and undifferentiated HL-60 cells or mouse splenocytes ${ }^{1}$

\begin{tabular}{lcccccc}
\hline & \multicolumn{5}{c}{ Relative viable cell number $(\%)$} \\
\cline { 2 - 7 } Pouligny $(\mu \mathrm{g} / \mathrm{mL})$ & 0 & 50 & 100 & 200 & 500 & 1,000 \\
\hline Differentiated cells & $100 \pm 5$ & $101 \pm 7$ & $93 \pm 5$ & $85 \pm 1$ & $74 \pm 2^{*}$ & $47 \pm 3^{*}$ \\
Undifferentiated cells & $100 \pm 5$ & $100 \pm 7$ & $83 \pm 4$ & $31 \pm 6^{*}$ & $11 \pm 2^{*}$ & $10 \pm 3^{*}$ \\
Mouse splenocytes & $100 \pm 4$ & $102 \pm 10$ & $90 \pm 2$ & $99 \pm 8$ & $77 \pm 10$ & $79 \pm 7$ \\
\hline
\end{tabular}

${ }^{1}$ Cells were incubated in the presence of varying concentrations of Pouligny Saint-Pierre cheese extract for 24 $\mathrm{h}$. In differentiated cells, cells were prepared following preincubation in the presence of $20 \mathrm{n} M$ phorbol 12 myristate 13-acetate for $48 \mathrm{~h}$ to achieve cellular differentiation (see Materials and Methods section). Data shown represent mean $\pm \mathrm{SD}$ derived from 4 determinations.

${ }^{*} P<0.001$ was considered statistically different from the relative viable cell number at $0 \mu \mathrm{g} / \mathrm{mL}$ Pouligny. 


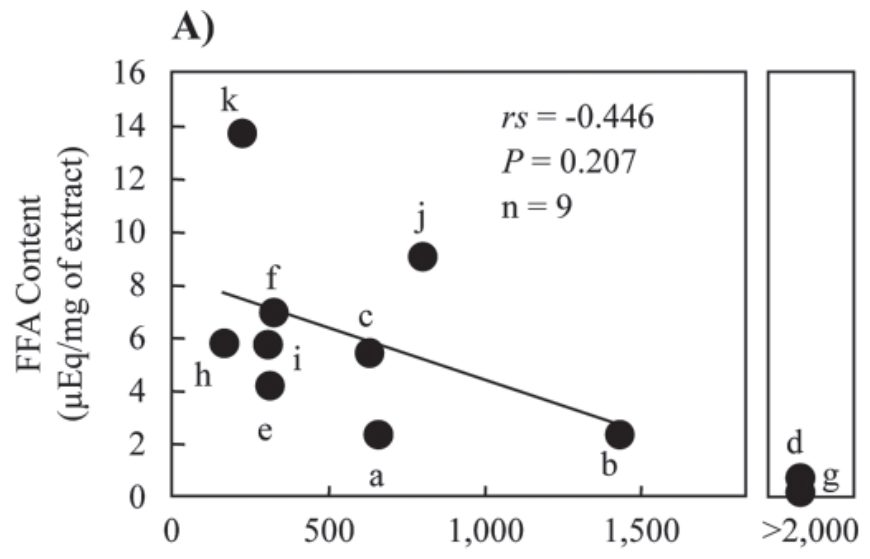

B)

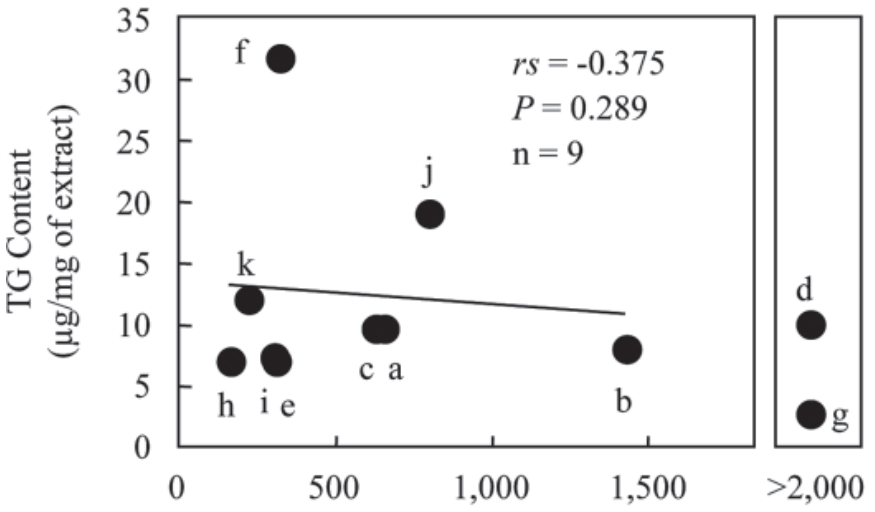

C)

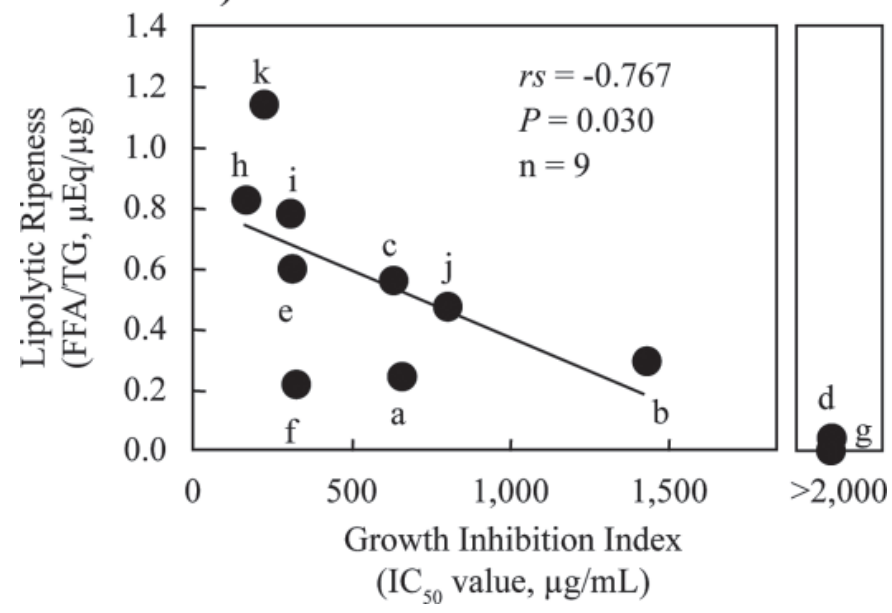

Figure 6. Relationship of commercial cheeses to the lipid contents and the growth inhibition index (half-maximal inhibitory concentration, $\mathrm{IC}_{50}$ value) determined in HL-60 cells. Analyses of FFA (A) and triglyceride (TG) contents (B) in cheese extracts were carried out according to the manufacturer's instructions (see Materials and Methods). Lipolytic ripeness (C) was calculated based on the ratio of FFA to TG contents. Each data point corresponds to cheese samples as follows: Banon (a), Buchettes (b), Chabichou du Poitou (c), cheese spread (d), Crottin de Chavignol (e), Kavli (f), Piramid Cendre (g), Pouligny Saint-Pierre (h), Sainte-Maure Soignon (i), Sainte-Maure de Touraine (j), and Valencay (k). Data represent mean values derived from 3 experiments of individual cheese samples. $P<0.05$ was considered statistically significant; $r s=$ Spearman rank correlation. efficient substrates for glutathione function, including detoxification of carcinogens, whereas lactoferrin and selenoproteins in milk can inhibit tumorigenesis (Parodi, 2007). Nevertheless, further investigation is needed to clarify what bioactive compounds might be present in goat cheeses, and whether the antiproliferative effect of cheeses found is specific not to normal cells but cancer cells in the human body. To establish cheeses as dairy products with health benefits, it is essential to clarify the multi-functional role of cheeses from goat and other ruminants.

\section{CONCLUSIONS}

In this paper, we demonstrated a potential antiproliferative effect of commercial goat cheeses using HL-60 human promyelocytic leukemia cells as a model. Among them, Pouligny Saint-Pierre goat cheese showed strong activity on the growth inhibition and induction of DNA fragmentation as well as protein expression of the activated form of caspase-3 in HL-60 cells. Based on the quantification of the ratio of FFA to TG in different cheese samples, highly lipolyzed cheeses were likely to possess strong antiproliferative activity. Whether the bioactive compounds present in these cheeses are responsible for the antiproliferative effect in the leukemic cell model studied, as well as in other leukemic cell lines, remains to be fully elucidated. Some other compounds from goat milk, such as cysteine-cysteine and $\gamma$-glutamylcyst(e)ine dipeptides, lactoferrin, and selenoproteins, rather than FFA, might have anticancer potential. However, results obtained in the current study may indicate a potential role of goat cheese products in suppressive effects on cancer cell growth, and lipolytic ripeness in cheeses can be considered as a key factor. More research is warranted to fully elucidate the beneficial contributions of fermented dairy products in cancer prevention.

\section{ACKNOWLEDGMENTS}

The authors thank Daijiro Hirayama and Yukari Takatsuka (School of Agriculture, Tokai University) for technical assistance. This work was supported in part by grant from Japan Dairy Association (Tokyo, Japan) and by Research and Study Program/Project of Tokai University Educational System General Research Organization (Kanagawa, Japan).

\section{REFERENCES}

Alonso, L., J. Fontecha, L. Lozada, M. J. Fraga, and M. Juarez. 1999. Fatty acid composition of caprine milk: Major, branched-chain, and trans fatty acids. J. Dairy Sci. 82:878-884. 
AOAC. 1995. Official Methods of Analysis, 16th ed. Association of Official Analytical Chemists, Washington, DC.

Attaie, R., and R. L. Richter. 1996. Formation of volatile free fatty acids during ripening of Cheddar-like goat cheese. J. Dairy Sci. 79:717-724.

Bradford, M. M. 1976. A rapid and sensitive method for the quantitation of microgram quantities of protein utilizing the principle of protein-dye binding. Anal. Biochem. 72:248-254.

Chujo, H., M. Yamasaki, S. Nou, N. Koyanagi, H. Tachibana, and K. Yamada. 2003. Effect of conjugated linoleic acid isomers on growth factor-induced proliferation of human breast cancer cells. Cancer Lett. 202:81-87.

Clark, S. B., S. B. Turnipseed, M. R. Madson, J. A. Hurlbut, L. R Kuck, and J. N. Sofos. 2005. Confirmation of sulfamethazine, sulfathiazole, and sulfadimethoxine residues in condensed milk and soft-cheese products by liquid chromatography/tandem mass spectrometry. J. AOAC Int. 88:736-743.

Collins, Y. F., P. L. H. McSweeney, and M. G. Wilkinson. 2003. Lipolysis and free fatty acid catabolism in cheese: A review of current knowledge. Int. Dairy J. 13:841-866.

Custodio, F. B., E. Tavares, and M. B. A. Gloria. 2007. Extraction of bioactive amines from grated Parmesan cheese using acid, alkaline and organic solvents. J. Food Compost. Anal. 20:280-288.

Dailey, O. D., Jr., X. Wang, F. Chen, and G. Huang. 2011. Anticancer activity of branched-chain derivatives of oleic acid. Anticancer Res. 31:3165-3169.

Das, D., G. Pintucci, and A. Stern. 2000. MAPK-dependent expression of p21(WAF) and p27(kip1) in PMA-induced differentiation of HL60 cells. FEBS Lett. 472:50-52.

de Moreno de LeBlanc, A., C. Matar, N. LeBlanc, and G. Perdigon. 2005. Effects of milk fermented by Lactobacillus helveticus R389 on a murine breast cancer model. Breast Cancer Res. 7:R477-R486.

Gorczyca, W., J. Gong, B. Ardelt, F. Traganos, and Z. Darzynkiewicz. 1993. The cell cycle related differences in susceptibility of HL-60 cells to apoptosis induced by various antitumor agents. Cancer Res. 53:3186-3192.

Havenaar, R. 2011. Intestinal health functions of colonic microbial metabolites: A review. Benef. Microbes 2:103-114.

Hijova, E., and A. Chmelarova. 2007. Short-chain fatty acids and colonic health. Bratisl. Lek Listy 108:354-358.

Igoshi, K., Y. Kondo, H. Kobayashi, K. Kabata, and H. Kawakami. 2008. Antioxidative activity of cheese. Milchwissenschaft 63:424426.

Inayat, S., M. A. Arain, M. Khaskheli, and A. H. Malik. 2003. Study of the effect of processing on the chemical quality of soft unripened cheese made from camel milk. Pak. J. Nutr. 2:102-105.

Ip, M. M., P. A. Masso-Welch, and C. Ip. 2003. Prevention of mammary cancer with conjugated linoleic acid: role of the stroma and the epithelium. J. Mammary Gland Biol. Neoplasia 8:103-118.

Ito, M., M. K. Roy, K. Kurihara, Y. Watanabe, Y. Kuwabara, S. Nagai, and Y. Tamai. 1998. Effects of bovine milk fermented by culturing with lactic acid bacteria and a yeast on the proliferation activity of human carcinoma cells. Food Sci. Technol. Int. 4:125-129.

Kampman, E., M. L. Slattery, B. Caan, and J. D. Potter. 2000. Calcium, vitamin D, sunshine exposure, dairy products and colon cancer risk (United States). Cancer Causes Control 11:459-466.

Kandaswami, C., L. T. Lee, P. P. Lee, J. J. Hwang, F. C. Ke, Y. T. Huang, and M. T. Lee. 2005. The antitumor activities of flavonoids. In Vivo 19:895-909.

Kawaii, S., and E. P. Lansky. 2004. Differentiation-promoting activity of pomegranate (Punica granatum) fruit extracts in HL-60 human promyelocytic leukemia cells. J. Med. Food 7:13-18.

Kimoto, H., K. Mizumachi, T. Okamoto, and J. Kurisaki. 2004. New Lactococcus strain with immunomodulatory activity: Enhancement of Th1-type immune response. Microbiol. Immunol. 48:75-82.

Kudoh, Y., S. Matsuda, K. Igoshi, and T. Oki. 2001. Antioxidative peptide from milk fermented with Lactobacillus delbrueckii ssp. bulgaricus IFO13953 . Nippon Shokuhin Kagaku Kaishi 48:44-55.

Kuhajda, F. P., K. Jenner, F. D. Wood, R. A. Hennigar, L. B. Jacobs, J. D. Dick, and G. R. Pasternack. 1994. Fatty acid synthesis: A potential selective target for antineoplastic therapy. Proc. Natl. Acad. Sci. USA 91:6379-6383.

Liu, X., H. Zou, C. Slaughter, and X. Wang. 1997. DFF, a heterodimeric protein that functions downstream of caspase-3 to trigger DNA fragmentation during apoptosis. Cell 89:175-184.

Mader, J. S., J. S. Salsman, D. M. Conrad, and D. W. Hoskin. 2005. Bovine lactoferricin selectively induces apoptosis in human leukemia and carcinoma cell lines. Mol. Cancer Ther. 4:612-624.

Matar, C., J. Amiot, L. Savoie, and J. Goulet. 1996. The effect of milk fermentation by Lactobacillus helveticus on the release of peptides during in vitro digestion. J. Dairy Sci. 79:971-979.

Matar, C., J. G. LeBlanc, L. Martin, and G. Perdigon. 2003. Biologically active peptides released in fermented milk: Role and functions. Pages 177-201 in Handbook of Fermented Functional Foods. E. R. Farnworth, ed. CRC Press, Boca Raton, FL.

McSweeney, P. L. H., and P. F. Fox. 1999. Cheese: Methods of chemical analysis. Pages 341-388 in. Cheese: Chemistry, Physics and Microbiology. Vol. 1. General Aspects. 2nd ed. P. F. Fox, ed. Aspen Publishers Inc., Gaithersburg, MD

Meisel, H. 2004. Multifunctional peptides encrypted in milk proteins. Biofactors 21:55-61.

Mir, Z., L. A. Goonewardene, E. Okine, S. Jaegar, and H. D. Scheer. 1999. Effect of feeding canola oil on constituents, conjugated linoleic acid (CLA) and long chain fatty acids in goats milk. Small Rumin. Res. 33:137-143.

Oda, T., A. Fujita, J. Xu, M. Mochizuki, K. Ukai, and M. Namikoshi. 2007. Effects of melophlins on colony formation of Chinese hamster V79 cells and IL-8 production in PMA-stimulated HL-60 cells. Mar. Drugs 5:1-5.

Parodi, P. W. 2007. A role for milk proteins and their peptides in cancer prevention. Curr. Pharm. Des. 13:813-828.

Phelan, M., and D. Kerins. 2011. The potential role of milk-derived peptides in cardiovascular disease. Food Funct. 2:153-167.

Poveda, J. M., and L. Cabezas. 2006. Free fatty acid composition of regionally-produced Spanish goat cheese and relationship with sensory characteristics. Food Chem. 95:307-311.

Rohrmann, S., J. Linseisen, M. U. Jakobsen, K. Overvad, O. Raaschou-Nielsen, A. Tjonneland, M. C. Boutron-Ruault, R. Kaaks, N. Becker, M. Bergmann, H. Boeing, K. T. Khaw, N. J. Wareham, T. J. Key, R. Travis, V. Benetou, A. Naska, A. Trichopoulou, V. Pala, R. Tumino, G. Masala, A. Mattiello, M. Brustad, E. Lund, G. Skeie, H. B. Bueno-de-Mesquita, P. H. Peeters, R. C. Vermeulen, P. Jakszyn, M. Dorronsoro, A. Barricarte, M. J. Tormo, E. Molina, M. Arguelles, B. Melin, U. Ericson, J. Manjer, S. Rinaldi, N. Slimani, P. Boffetta, A. C. Vergnaud, A. Khan, T. Norat, and P. Vineis. 2011. Consumption of meat and dairy and lymphoma risk in the European Prospective Investigation into Cancer and Nutrition. Int. J. Cancer 128:623-634.

Roy, M. K., Y. Kuwabara, K. Hara, Y. Watanabe, and Y. Tamai. 2002. Peptides from the N-terminal end of bovine lactoferrin induce apoptosis in human leukemic (HL-60) cells. J. Dairy Sci 85:2065-2074.

Roy, M. K., Y. Watanabe, and Y. Tamai. 1999. Induction of apoptosis in HL-60 cells by skimmed milk digested with a proteolytic enzyme from the yeast Saccharomyces cerevisiae. J. Biosci. Bioeng. $88: 426-432$.

Schul, D., D. Tallmadge, D. Burress, D. Ewald, B. Berger, and D. Henry. 1998. Determination of fat in olestra-containing savory snack products by capillary gas chromatography. J. AOAC Int. 81:848-868.

Sousa, M. J., Y. Ardob, and P. L. H. McSweeney. 2001. Advances in the study of proteolysis during cheese ripening. Int. Dairy J. 11:327-345.

Suh, N., L. Luyengi, H. H. Fong, A. D. Kinghorn, and J. M. Pezzuto. 1995. Discovery of natural product chemopreventive agents utilizing HL-60 cell differentiation as a model. Anticancer Res. 15:233-239.

Tanabe, S., S. Tesaki, J. Watanabe, E. Fukushu, K. Sonoyama, and J. Kawabata. 2003. Isolation and structural elucidation of a peptide derived from Edam cheese that inhibits $\beta$-lactoglobulin transport. J. Dairy Sci. 86:464-468. 
Urista, C. M., R. A. Fernaandez, F. R. Rodriguez, A. A. Cuenca, and A. T. Jurado. 2011. Review: Production and functionality of active peptides from milk. Food Sci. Technol. Int. 17:293-317.

Walters, M. J. 1984. Determination of histamine in fish by liquid chromatography with post-column reaction and fluorometric detection. J. Assoc. Off. Anal. Chem. 67:1040-1043.

Watanabe, T. 1996. Suppressive effects of Lactobacillus casei cells, a bacterial immunostimulant, on the incidence of spontaneous thymic lymphoma in AKR mice. Cancer Immunol. Immunother. 42:285-290.

Wong, J. M., R. de Souza, C. W. Kendall, A. Emam, and D. J. Jenkins. 2006. Colonic health: Fermentation and short-chain fatty acids. J. Clin. Gastroenterol. 40:235-243.

Woo, A. H., S. Kollodge, and R. C. Lindsay. 1984. Quantification of major free fatty acids in several cheese varieties. J. Dairy Sci. $67: 874-878$.

Xu, X. X., H. R. Jiang, H. B. Li, T. N. Zhuang, G. Zhou, and N. Liu. 2010. Apoptosis of stomach cancer cell SGC-7901 and regulation of Akt signaling way induced by bovine lactoferrin. J. Dairy Sci. 93:2344-2350.
Yamada, K., M. Sasaki, and G. Kimura. 1985. Effect of sodium butyrate on actin distribution in rat $3 \mathrm{Y} 1$ fibroblasts in monolayer culture. J. Cell. Physiol. 125:235-242.

Yamamoto, N., M. Maeno, and T. Takano. 1999. Purification and characterization of an antihypertensive peptide from yogurt-like product fermented by Lactobacillus helveticus CPN4. J. Dairy Sci. 82:1388-1393.

Yamasaki, M., A. Mukai, M. Ohba, Y. Mine, Y. Sakakibara, M. Suiko, K. Morishita, and K. Nishiyama. 2010. Genistein induced apoptotic cell death in adult T-cell leukemia cells through estrogen receptors. Biosci. Biotechnol. Biochem. 74:2113-2115.

Yasuda, S., N. Ohkura, K. Suzuki, M. Yamasaki, K. Nishiyama, H. Kobayashi, Y. Hoshi, Y. Kadooka, and K. Igoshi. 2010. Effects of highly ripened cheeses on HL-60 human leukemia cells: Antiproliferative activity and induction of apoptotic DNA damage. J. Dairy Sci. 93:1393-1400.

Yu, F., S. Lu, F. Yu, J. Shi, P. M. McGuire, and R. Wang. 2008 Cytotoxic activity of an octadecenoic acid extract from Euphorbia kansui (Euphorbiaceae) on human tumor cell strains. J. Pharm. Pharmacol. 60:253-259. 